\title{
EDITORIAL: 20 YEARS OF PRINCIPIA Dedicated TO THE MEMORY OF PRof. OSWALdo Porchat
}

In this year of 2017 we celebrate 20 years of the journal Principia. We are happy about the success in the organization of the $10^{\text {th }}$ Principia International Symposium, but we also lament the loss of our first editor, Professor Oswaldo Porchat de Assis Pereira da Silva, who passed away on October $15^{\text {th }}$. Porchat was Professor Emeritus at the University of São Paulo (USP) and at the University of Campinas (Unicamp), where he was one of the founders of the Philosophy Department and of the Center for Logic and Epistemology (CLE). We, the editors of Principia, are proud of carrying on the work of this great Brazilian philosopher.

This editorial aims to tell a bit of the journal's history and, thus, to understand its present. To do that, we interviewed one of its founders, Professor Luiz Henrique de Araújo Dutra. Professor Dutra, who is currently Full Professor at Federal University of Santa Catarina (UFSC), succeeded Oswaldo Porchat as editor-in-chief (the function currently known as executive editor) in 2005 and remained in charge until 2015. Still today, Professor Dutra is a member of the journal's Editorial Team, in a position in which his broad experience helps and supports the work of the other editors. We dedicate this editorial and this interview to the memory of Professor Porchat. With this we hope to contribute in the telling of a history that he helped to build.

$* * *$

Q: The journal was founded in 1997 . What was the motivation back then?

DUTRA: The main motivation to create the journal was that of having in Brazil a philosophical journal with a specific focus on the area of epistemology. More than that, an international-level journal that published not only in Portuguese, but also in English, French, and Spanish. Indeed, the journal was part of a larger project we had. The two other important parts of this project were UFSC's Philosophy Graduate Program and NEL (Epistemology and Logic Research Group). NEL aimed not only at publishing the journal, but also at promoting various academic activities, such as the Principia Symposia a few years afterwards. The Philosophy Graduate Program began its activities in the same year of 1997, with only a Master's course and concentrating only on epistemology. Besides Prof. Cupani, who was the first coordinator of the Program, and myself, the following Professors were part of the epistemology area of our department: Sara Albieri, Renato Machado, Marco Antonio Franciotti, Cezar Augusto Mortari, Gustavo Caponi and Antônio Mariano Coelho.

Principia 21(2): 163-166 (2017).

Published by NEL — Epistemology and Logic Research Group, Federal University of Santa Catarina (UFSC), Brazil. 
Q: And how was the participation of Professor Porchat?

DUTRA: Oswaldo Porchat had been a professor or advisor of some of us and he was an important academic reference in the area - not only for his work at Unicamp, as founder of both CLE and the Philosophy Department, but also for his philosophical work, with many important contributions in the studies on Skepticism. I was quite close to him at the time, as well as I was part of of the workgroup on that topic, of which he was the leader. This workgroup generated two current ANPOF (Brazilian National Philosophical Association) workgroups. To the exception of Professor Cupani, who was already an experienced researcher, the others in our group at UFSC were beginners and we wanted a heavyweight name to direct the journal, but it should be someone who had a real scholar and intellectual relation with us. Hence we decided to invite Professor Porchat to be the journal's editor. He was a bit reluctant at first, for he didn't want to take up bureaucratic duties. But he accepted because of the support he would give to our group, as he recognized our potential. The many associate editors that our journal had since then liberated him from the heavier bureaucratic tasks.

Q: Who were the other editors?

DUTRA: During the period in which Professor Porchat was the journal's responsible editor, the associate editors were Alberto Cupani, Cezar Mortari and myself, in different moments. When I became the journal's responsible editor in 2005, Prof. Mortari went on as associate editor and others were joining the group, such as Jaimir Conte, Jonas Becker Arenhart and Ivan F. da Cunha.

Q: Which were the main difficulties faced by the journal?

DUTRA: Until the introduction of electronic publishing, the main difficulty was the lack of financial resources to publish on paper. And an important difficulty we've ever had is the absence of at least one person who compromises to work permanently on the journal. This became less dramatic after we began publishing electronically, and chiefly in virtue of the dedication of Professors Mortari and Conte. In the beginning, to make it feasible to publish we sought a partnership with Editora da UFSC (the University Press of UFSC), with which the first issues of the journal came out. In a short while, we realized that this partnership was more of a nuisance than a real help. It solved the financial problem, but it brought a series of editorial impositions. As a matter of fact, things improved as soon as we left the partnership with Editora da UFSC and assumed the publishing entirely. We still had to look for occasional financial support, but it all became easier with the on-line system.

Q: How did the idea of organizing the Symposia come up?

DUTRA: The history of the Symposia begins much before, as it relates to the Meetings on Analytic Philosophy, a initiative taken by Professor Maria Cecília Carvalho, from PUC-Campinas (Pontifical Catholic University of Campinas). She organized two of these

Principia 21(2): 163-166 (2017). 
meetings, which were a great success. We took up the organization of the two following meetings of the series. After that, however, the people who undertook the organization of the fifth meeting couldn't do it. So, we had the idea of starting a new series of meetings linked to NEL and to Principia, but we gave up the old name to avoid misunderstandings. In spite of being conceived to be smaller meetings, the Principia Symposia have promptly acquired general acclaim and were regarded as the continuation of those meetings. The fact is that the Principia Symposia developed throughout the years as the main philosophy meeting in Brazil after the ANPOF meetings, having an international projection as well.

Q: In your opinion, what is Principia's main contribution to the Brazilian philosophical community?

DUTRA: It is forceful to compare Principia to another Brazilian philosophical journal, much older and better consolidated, Manuscrito. This comparison is pertinent for us to highlight the fact that, albeit much younger, Principia has readily achieved the same level of excellence of that Unicamp journal. And, as a matter of fact, Principia is currently better-known internationally as a Latin-american reference of high-quality philosophical publishing. Thus, this is the main contribution of our journal, that of being the main philosophical publication in Brazil nowadays. This is no exaggeration, even with the acknowledgment of other publications in the area, such as USP's Scientiae Studia.

Q: If we compare the scholar and philosophical environment in which the journal appeared and the situation we have today, what changes can we notice?

DUTRA: The most significant change is that today we have a philosophical community that is not only numerically larger, but that presents such a high level of quality and international recognition, which did not exist in the last decade of the last century. This change is essentially due to the consolidation of the many Philosophy Graduate Programs in Brazil, a process which has as contributors not only our own Program, but also, to a great extent, our journal and the Principia Symposia. The current situation is much better professionally, since we are no longer a small community in the periphery, dominated by powerful little groups; we became a big community of competent, productive and well-recognized researchers with multiple leaderships that are, most of the times, of a genuinely philosophical, eminently scholarly character.

As stated above, we seek with this interview to register a little portrait of our journal's past and present. This commemorative edition brings as well six articles that compose a portrait of our current activity and that, we hope, might contribute to the future of our debates. We received and published the texts of six of the invited speakers of the $10^{\text {th }}$ Symposium, including Professor Luiz Henrique Dutra himself. These 
six articles deal with the theme we chose for the $10^{\text {th }}$ Symposium, The Construction of Experience. Such a choice was in virtue of the fact that this theme pervades many areas of philosophy and that it acquires a central role in many contemporary discussions. The main conferences of the Symposium dealt with the theme from many points of view and in diverse approaches, contributing thus to the direction of the exchange of ideas that happened in the event. Those who showed up at the Castelmar Hotel in Florianópolis between the $14^{\text {th }}$ and the $17^{\text {th }}$ of August of 2017 had the opportunity to witness deep and comprehensive debates. This leads us to the conclusion that our choice of theme and of invited speakers was successful. We thank all those who helped in the success of the $10^{\text {th }}$ Principia International Symposium. And we hope, in order to celebrate the 20 years of Principia, that the six papers here published motivate even more discussions.

The articles are the following:

A Construção da Experiência Perceptiva. O que isso quer dizer? [The Construction of Perceptual Experience. What does it mean?], by Gary Hatfield (University of Pennsylvania, EUA), translated by Ivan Ferreira da Cunha and Renato Cesar Cani from an original contribution by Professor Hatfield.

Inferência Metafísica e a Experiência do Observável [Metaphysical Inference and Experiencing the Observable], by Anjan Chakravartty (University of Notre Dame, EUA), translated by Ivan Ferreira da Cunha and Raoni Wohrath Arroyo from an original contribution by Professor Chakravartty.

Experience and Mathematical Knowledge, by Rodolfo Gaeta (Universidad de Buenos Aires, Universidad Nacional de Luján, Argentina).

A Experiência Perceptual na Perspectiva da Teoria da Percepção Direta [Perceptual Experience in the Perspective of the Theory of Direct Perception], by Mariana C. Broens (Universidade Estadual Paulista, Brasil).

Intentionality and Continuity of Experience, by André Leclerc (Universidade de Brasília, Brasil).

A beleza está nos olhos de quem a vê? A percepção de realidades abstratas [Is beauty in the eyes of the beholder? The perception of abstract realities], by Luiz Henrique de Araújo Dutra (Universidade Federal de Santa Catarina, Universidade de Brasília, Brasil).

Principia 21(2): 163-166 (2017). 